\title{
PEMBAHARUAN HUKUM DALAM KOMPILASI HUKUM ISLAM
}

\author{
A. Intan Cahyani
}

Fakultas Syariah dan Hukum Universitas Islam Negeri (UIN) Alauddin Makassar

\begin{abstract}
In the context of the Compilation of Islamic Law, Islamic law is seen as a renewal of the mandate of the state constitution to replace the products of the Dutch colonial laws still in force and to replace some legal product that was not commensurate with the demands of the times. Islamic law in the context of Indonesian-ness especially those in family law reform includes four categories, namely: figh, fatwa, jurisprudence, and Act. Compilation of Islamic Law is a formulation of jurisprudence ala Indonesia that serve as a guide and reference of Indonesian Muslims. $\mathrm{KHI}$ as a definition of jurisprudence, necessitates to be interpreted according to the context. This can be seen in some of the provisions of existing laws in $\mathrm{KHI}$.
\end{abstract}

Keywords:

Islamic Law, Reform, Islamic Law Compilation.

\begin{abstract}
Abstrak
Dalam konteks Kompilasi Hukum Islam, pembaharuan hukum Islam dipandang sebagai amanah konstitusi negara untuk menggantikan produk-produk hukum kolonial Belanda yang masih berlaku dan untuk menggantikan beberapa produk hukum yang dipandang tidak sesuai dengan tuntutan zaman. Hukum Islam dalam konteks keindonesiaan terkhusus dalam pembaharuan hukum keluarga meliputi empat kategori, yaitu: fikih, fatwa, yurisprudensi, dan Undang-Undang. Kompilasi Hukum Islam merupakan rumusan fikih ala Indonesia yang dijadikan sebagai pedoman dan rujukan umat Islam Indonesia. KHI sebagai rumusan fikih, meniscayakan untuk ditafsir sesuai dengan konteksnya. Hal tersebut dapat dilihat dalam beberapa ketentuan hukum yang ada dalam KHI.
\end{abstract}

Kata Kunci:

Hukum Islam, Pembaharuan, Kompilasi Hukum Islam. 


\section{A. PENDAHULUAN}

$\mathrm{P}$ embaharuan hukum Islam pada dasarnya bertolak pada sesuatu yang telah ada (existing), kemudian mengalami perubahan secara kualitatif sebagai produk interaksi dalam kehidupan masyarakat. Dapat dikatakan bahwa proses pembaharuan hukum Islam dipandang sebagai sesuatu yang otonom, akan tetapi ia pun berinteraksi dengan unsur lain dalam masyarkat sehingga terjadi saling bergantung. Ketika hukum Islam berinteraksi dengan kehidupan sosial maka masyarakat senantiasa dihadapkan pada masalah baik yang bersifat internal maupun eksternal. Oleh karena itu, konsep pembaharuan hukum Islam menuntut adanya sikap adaptatif dengan kondisi sosial masyarakat di mana ia berinteraksi. Dalam hal ini, perwujudan kaidah al-muhafadzah 'ala al-qadim al-shalih wa al-akhdzu 'ala al-jadid al-ashlah (memelihara yang lama jika hal itu masih baik dan menerima yang baru atau perubahan jika hal itu dianggap lebih baik), menjadi suatu keharusan. Hal ini penting karena perilaku mukallaf yang menjadi obyeknya dipandang sebagai sesuatu yang kontinum dan senantiasa mengalami perubahan.

Dengan demikian pembaharuan hukum Islam harus dilakukan dalam memberikan respon terhadap tuntutan perubahan yang terjadi di tengah-tengah masyarakat. Dikatakan demikian karena salah satu bentuk dari universalitas hukum Islam dilihat dari daya adaptabilitas dan fleksibilitas hukum Islam itu sendiri. Itu berarti bahwa pemikiran hukum Islam tidak konstan dalam satu zaman, tempat, dan keadaan, melainkan senantasa mengalami perubahan secara dinamis seiring dengan perubahan zaman, tempat, dan keadaan. Hal ini sesuai dengan pendapat al-Jauziyah تغير الفتاوى والتلافها بحسب تغير الازمة والامكنة والاحو ال والنيات والعو اءد yang mengatakan (perubahan ide-ide atau pemikiran hukum dan perbedaannya sesuai dengan perubahan zaman, ruang, keadaan, niat, dan kebutuhan). Bahkan lebih jauh alJauziyah mengatakan bahwa tidak memahami (mempertimbangkan, pen.) perubahan, merupakan kesalahan besar dalam syari' at. ${ }^{1}$

Kendatipun pembaharuan hukum Islam dipandang sebagai suatu keharusan, akan tetapi perlu ditegaskan bahwa pembaharuan hukum Islam yang meliputi segala bentuk muamalah diizinkan oleh syari'at Islam, sepanjang tidak kontra produktif dengan jiwa dan roh hukum Islam itu sendiri. Dikatakan demikian karena hukum Islam dalam bidang muamalah hanya mengatur dan menetapkan prinsipprinsip pokoknya secara umum, sedangkan perinciannya diserahkan kepada manusia untuk memikirkannya, dengan catatan tetap berangkat dari prinsip dasar yang dikehendaki oleh hukum Islam itu sendiri. Dalam hal ini dapat dikatakan bahwa jiwa dan prinsip hukum Islam bersifat konstan, permanent, stabil, dan tidak berubah sepanjang masa. Akan tetapi, terhadap peristiwa hukum, teknis dan cabang-cabangnya, dapat mengalami perubahan dan pembaharuan sesuai dengan

${ }^{1}$ Lihat Ibnu Qayyim al-Jauziyyah, I'lam al-Muwaqqi'in 'an Rab al- 'Alamin, Juz III (Beirut: Dar al-Fikr, t.th.), h. 14 . 
tuntutan zaman. ${ }^{2}$

Salah satu aspek yang paling penting dalam kehiduan muamalah adalah masalah hukum keluarga. Dalam kaitan ini J.N.D. Anderson mengatakan bahwa hukum keluarga dianggap sebagai inti syari'ah, karena bagian inilah yang oleh umat Islam dianggap sebagai pintu gerbang untuk masuk lebih jauh ke dalam wilayah agama dan masyarakat. ${ }^{3}$ Hukum keluarga sebagai bagian penting dalam hukum Islam, tidak luput dari gagasan pembaharuan sebagaimana dengan bagian hukum Islam lainnya. Bahkan pembaharuan hukum Islam telah menjadi wacana yang menglobal di seluruh dunia Islam, khususnya di Indonesia yang hukum keluarganya telah diformulasi dan dikenal dengan Kompilasi Hukum Islam (KHI).

Berdasar pada latar belakang tersebut di atas, maka dapatlah ditarik sebuah rumusan masalah dengan pokok masalah Bagaimana Pembaharuan Hukum dalam Kompilasi Hukum Islam. Adapun yang menjadi sub masalahnya adalah sebagai berikut: Bagaimana Pembaharuan Hukum Islam di Indonesia dan Bagaimana Pembaharuan Hukum Materil dalam Kompilasi Hukum Islam.

\section{B. PEMBAHASAN}

\section{Paradigma Pembaharuan Hukum Islam di Indonesia.}

Secara garis besarnya, hukum Islam meliputi empat bidang, yaitu: pertama, bidang ibadah, yakni merupakan penataan hubungan antara manusia dengan Allah swt. Kedua, bidang munakahat, merupakan penataan hubungan antara manusia dengan lingkungan keluarga. Ketiga, bidang muamalah, merupakan penataan hubungan antara manusia dengan pergaulan hidup masyarakat. ${ }^{4}$ Sedangkan menurut A. Jazuli, hukum Islam meliputi: bidang ibadah, bidang ahwal alSyakhsiyyah (perkawinan, kewarisan, wasiat, dan wakaf), bidang muamalah (dalam arti sempit), bidang jinayah, bidang aqdhiyyah (peradilan), dan bidang siyasah (dusturiyah, maliyah, dan dauliyah). ${ }^{5}$

Pembidangan hukum Islam tersebut, sejalan dengan perkembangan pranata sosial, sebagai norma yang berfungsi untuk memenuhi kebutuhan manusia dalam kehidupan individual dan kolektif. Oleh karena itu, semakin beragam kehidupan manusia dan semakin beragam pranata sosial, maka semakin berkembang pula pemikiran ulama dan pembidangan hukum Islam pun mengalami perkembangan. Hal itu menunjukkan, terdapat korelasi positif antara perkembangan pranata sosial dengan pemikiran ulama secara sistematis. Atau sebaliknya, penyebarluasan produk pemikiran ulama yang mengacu kepada firman Allah melahirkan berbagai pranata

${ }^{2}$ Lihat Rahmat jatnika, Jalan Mencari Hukum Islam Upaya ke Arah Pemahaman metodologi Ijtihad, dalam Amrullah Ahmad SF., Dimensi Hukum Islam dalam Sistem hukum Nasional, Cet. I (Jakarta: Gema Insani Press, 1996), h. 106-107.

${ }^{3}$ J.N.D. Anderson, Islamic law in Moderen World, alih bahasa oleh Machnun Husain, dengan judul: Hukum Islam di Dunia Moderen (Cet.I; Surabaya: Amar Press, 1991), h. 42.

${ }^{4}$ Lihat, Ali Yafi, Fikih Sosial (Cet. I; Bandung: Mizan, 1995), h. 132.

${ }^{5}$ Lihat, A. Jazuli, Ilmu Fikih: Sebuah Pengantar (Cet.I; Bandung: Orba Shakti, 1991), h. 54. 
sosial. ${ }^{6}$

Hukum Islam yang termaktub di dalam ayat-ayat ahkam, hadis-hadis ahkam, dan terutama di dalam kitab-kitab fikih dipahami terus mengalami perkembangan. Dalam proses pengembangan, hukum Islam mengalami internalisasi ke dalam berbagai pranata sosial yang tersedia di dalam masyarakat. Terjadi proses alokasi hukum Islam dalam dimensi syari'ah ke dalam pranata sosial, menjadi landasan dan memberi makna serta arah dalam kehidupan masyarakat Islam Indonesia. Hasil dari proses pengembangan hukum Islam yang terjadi dalam rentan waktu berabad-abad, berkembang berbagai pranata sosial yang bercorak keislaman. ${ }^{7}$

Pranata-pranata sosial dapat dilihat dalam dua sudut pandang, yaitu: pertama, ia merupakan aktualisasi hukum Islam yang tertumpu kepada interaksi sosial yang mempola setelah mengalami pergumulan dengan kaedah-kaedah lokal dianut oleh masyarakat Indonesia yang majemuk. Dalam pergumulan itu, terjadi adaptasi dan modifikasi antara hukum Islam dan kaedah lokal. Dengan perkataan lain bahwa proses sosialisasi dan institusionalisasi hukum Islam terjadi dalam hubungan timbal balik dengan kaedah-kaedah lokal yang dianut. Selain itu, terjadi interpensi hukum Barat terutama sejak masa penjajahan Belanda.

Kedua, pranata-pranata sosial merupakan perwujudan interaksi sosial di dalam masyarakat Islam untuk memenuhi kebutuhan hidup mereka. Interaksi sosial itu berpatokan dan mengacu kepada keyakinan (kesepakatan tentang benar dan salah), nilai (kesepakatan tentang baik dan buruk), dan kaedah (kesepakatan tentang yang mesti dilakukan dan yang mesti tidak dilakukan), yang dianut oleh mereka. Ia merupakan perwujudan amal shaleh sebagai ekspresi keimanan dalam interaksi sosial.

Dalam kehidupan masyarakat Islam Indonesia dewasa ini, dikenal berbagai pranata sosial yang bercorak keislaman. Pranata-pranata sosial meiputi berbagai bidang kehidupan, yang senantisa mngalami perkembangan dari waktu ke waktu. Ada pranata yang amat dekat dengan keyakinan yang dianut, sehingga memiliki tingkat kepekaan yang sangat tinggi, seperti pranata peribadatan, pranata kekerabatan, dan pranata pendidikan. Ada pula pranata sosial yang agak jauh dari keyakinan, sehingga relatif luwes dan netral, seperti pranata ekonomi dan pranata keilmuan, sehingga poses adaptasiya relativf longgar dan labelnya sebagai hukum Islam bersifat luwes. Selanjutnya pranata-pranata sosial mengalami konkretisasi dalam struktur masyarakat, dalam bentuk berbagai organisasi sosial sebagai wahana untuk memenuhi kebutuhan hidup secara kolektif dan terencana. Kenyataan itu menunjukkan bahwa di dalam masyarakat terjadi penyerapan produk teknologi sosial (pengorganisasian masyarakat) mutakhir, dan dapat dijadikan saluran untuk mengaktualisasikan hukum Islam di dalam kehidupan nyata. ${ }^{8}$

\footnotetext{
${ }^{6}$ Cik Hasan Bisri, Menggagas Fikih Sosial (Cet. I; Mizan: 1995), h. 132.

${ }^{7}$ Cik Hasan Bisri, Menggagas Fikih Sosial, h. 116.

${ }^{8}$ Cik Hasan Bisri, Menggagas Fikih Sosial, h. 118
} 
Dengan demikian, pembatuan hukum Islam sebagai aktualisasi perintah Allah mempunyai beragam bentuk dan mencakup beragam pranata sosial. Oleh karena itu, pembaharuan hukum Islam di Indoneisa terpola pada internalisasi hukum Islam ke dalam pranata-pranata sosial atau sebaliknya pranata sosial terinternalisasi ke dalam hukum Islam. Pada konteks ini tampak relasi yang saling mendukung antara hukum Islam dan pranata sosial.

Dalam konteks tersebut, pembaharuan hukum Islam di Indonesia meliputi empat kategori, yaitu:

1. Fikih

Salah satu wujud hukum Islam yang sistimatis dan rinci adalah fikih. Secara garis besarnya fikih meliputi empat bidang, yaitu: pertama, ibadah merupakan penataan hubungan antara manusia dengan Tuhan. Kedua, bidang munakahat yang merupakan penataan hubungan antar manusia dengan lingkungan keluarga. Ketiga, bidang muamalah, merupakan penataan hubungan antar manusia dalam pergaulan kemasyarakatan. Keempat, bidang jinayah merupakan penataan pengamanan dalam suatu tata tertib pergaulan yang menjadi keselamatan dan ketentraman dalam hidup bermasyarakat. ${ }^{9}$

Fikih sebagai produk pemikiran hukum Islam, baru berkembang pada masa sahabat sepeninggal Rasulullah. Hal itu disebabkan oleh karena pada masa kenabian karena setiap persoalan yang ada dengan mudah dapat diselesaikan oleh Nabi sendiri melalui wahyu dan sabda-sabdanya. Muncul dan berkembangnya kajiankajian fikih disebabkan oleh munculnya persoalan-persoalan akibat semakin meluasnya wilayah Islam dan semakin besarnya jumlah umat Islam dengan latar belakang etnis dan kultur yang berbeda. ${ }^{10}$ Oleh karena masalah-masalah yang muncul itu belum pernah dialami oleh Rasululah dan tidak terdapat nash secara jelas dan tegas tentang hal itu, maka para sahabat dan generasi berikutnya dituntut untuk berpikir dalam menyelesaikan masalah-masalah yang ada.

Sekaitan dengan hal tersebut fikih sebagai produk pemikiran hukum Islam di Indonesia, karakteristiknya sangat kental dengan kepribadian Arab. Hal itu disebabkan oleh karena jaringan intelektual para fuqaha Indonesia terlalu Arab oriented. Kondisi seperti ini berlangsung hingga paro pertama abad ke-20. ${ }^{11}$ Pada konteks ini, Hasbi ash-Shiddieqy mengatakan bahwa terdapat bagian-bagian fikih kaum muslimin Indonesia yang didasarkan pada 'urf timur tengah yang tidak sesuai dengan rasa kesadaran hukum masyarakat Indonesia yang melembaga dalam hukum adat. Atas dasar itulah sehingga fikih kurang mendapat sambutan hangat dari masyarakat Indonesia, karena dianggap kurang sesuai dengan kepribadian bangsa Indonesia. ${ }^{12}$

\footnotetext{
${ }^{9}$ Ali Yafi, Fikih Sosial, h. 132.

${ }^{10}$ Dede Rosada, op.cit., h. 5

${ }^{11}$ Marzuki Wahid dan Rumadi, Fikih Mazhab Negara (Cet. I; Yogyakarta: LkiS, 2001), h. 129.

${ }^{12}$ Hasbi ash-Shiddiqy, Syari'at Islam Menjawab Tantangan Zaman (Jakarta: Bulan Bintang, 1966), h. 41-
} 42. 
Keterasingan fikih itu sebagaimana yang disinyalir oleh Hasbi ash-Shiddiqy tersebut antara lain juga disebabkan oleh pandangan fikih yang terlalu formalistik. Kecenderungan fikih yang demikian menjadikan sebagai paradigma kebenaran ortodoks, dimana semua realitas tunduk pada kebenaran fikih. Penekanan yang terlalu berlebihan pada formalisme dan kecenderungan melakukan teologisasi fikih, menyebabkan fikih Indonesia seolah-olah menjauhi diri dari realitas sosial dan kultur masyarakat yang menjadi obyeknya. ${ }^{13}$

Oleh karena itu, sudah saatnya dipikirkan upaya untuk menggeser paradigma fikih ortodoksi kepada paradigma fikih berwawasan sosial-budaya, yaitu melakukan pembaharuan fikih yang ramah dengan kultur dan budaya bangsa Indonesia dengan tetap berpegang pada prinsip-prinsip universal hukum Islam, yaitu memelihara agama, akal, jiwa, kehormatan, dan harta. Jika paradigma pertama memperlihatkan hitam putih Islam memandang realitas, maka yang kedua memperlihatkan watak yang bernuansa kultural. Kiranya gagasan Gus- Dur terntang pribumisasi Islam patut mendapat sambutan dan kajian lebih jauh dalam upaya pembaharuan fikih sebagai produk pemikiran hukum Islam yang berwawasan budaya yang mempertimbangkan kearifan-kearifan lokal.

\section{Fatwa}

Fatwa adalah hasil ijtihad seorang mufti sehubungan dengan peristiwa hukum yang diajukan kepadanya. Produk pemikiran hukum Islam dalam kategori fatwa, diantara cirinya adalah bersifat kasuistik, karena merupakan respon atau jawaban atas pertanyaan yang diajukan oleh peminta fatwa. Berbeda dengan putusan pengadilan, fatwa tidak mempunyai daya ikat dan daya paksa, dalam arti bahwa yang meminta fatwa tidak harus mengikuti isi atau hukum yang diberikan kepadanya. Demikian pula masyarakat luas tidak harus terikat dengan fatwa tersebut, karena fatwa seorang ulama di suatu tempat bisa berbeda dengan fatwa ulama lain ditempat yang sama. Biasanya fatwa cenderung bersifat dinamis karena merupakan respon terhadap perkembangan baru yang sedang dialami oleh orang atau sekelompok orang yang meminta fatwa. Isi suatu fatwa belum tentu dinamis, akan tetapi sikap responnya itu yang sekurang-kurangnya dapat dikatakan dinamis. Meskipun fatwa itu dikeluarkan secara kasuistik, namun sejumlah fatwa dari ulama besar atau lembaga keagamaan dan hukum telah dibukukan, akan tetapi sistematikanya tetap berbeda dengan fikih. ${ }^{14}$

Dalam sejarah, pelaksanaan pemberian fatwa dimulai sejak agama Islam meluaskan wilayah pengaruhnya pada abad ke-7 dan ke-8. Kaum muslimin menghadapi berbagai persoalan-persoalan baru dengan cepat. Bagi mereka yang tinggal di kota-kota besar, umumnya mereka menyelesaikan persoalan-persoalan yang dihadapi melalui lembaga peradilan atau hakim-hakim yang dapat

\footnotetext{
${ }^{13}$ Marzuki Wahid dan Rumadi, Fikih Mazhab Negara, h. 130-131.

${ }^{14}$ M. Atho Mudzhar, Fatwa-Fatwa Majelis Ulama (Cet. I; Jakarta: INIS, 1993), h. 3.
} 
menyelesaikan persoalan. Akan tetapi bagi mereka yang tinggal jauh dari kota-kota besar, biasanya dalam menyeleaikan persoalannya cukup bertanya atau meminta fatwa kepada orang yang dianggap pintar. ${ }^{15}$

Di Indonesia, pembaharuan hukum Islam dalam kategori fatwa dilakukan oleh organisasi-organisasi kemasyarakatan seperti NU, Muhammadiyah, dan persis. Masing-masing organisasi mempunyai lembaga khusus yang melakukan pembaharuan hukum Islam dalam bentuk fatwa. Dalam lingkungan NU adalah dilakukan oleh Majels Syuriah dan Majelis Ahlu al-Hall wa al-'Aqdi, di lingkungan MUI oleh Komisi fatwa, di Muhammadiyah oleh majelis Tarjih dan persis oleh Dewan Hisbah. Pembaharuan hukum Islam melalui organisasi ini memiliki kegunaan praktis terutama bagi yang membutuhkannya, baik oleh pemerintah maupun oleh para pemimpin dan anggota masyarakat, pada gilirannya fatwa dapat menjadi acuan dalam penerapan hukum Islam. ${ }^{16}$

\section{Putusan Hakim (Yurisprudensi)}

Dalam kepustakaan hukum anglo saxon, perkataan yurisprdensi mengandung arti yang lebih luas dari perkataan yurisprudensi dalam hukum Eropa Kontinental. Di dalam kepustakaan anglo saxon, yurisprudensi selain bermakna hukum (dalam putusan) hakim, juga bermakna filsafat hukum dalam ilmu hukum. Sedangkan dalam kepustakan Eropa Kontinental dan dalam kepustakaan Hukum Indonesia, yang disebut yurisprudensi adalah kumpulan keputusan Mahkamah Agung (dan Pengadilan Tinggi) mengenai perkara tertentu berdasarkan pertimbangan (kebijaksanaan) hakim sendiri yang diikuti sebagai pedoman oleh hakim lain dalam memutus perkara yang sama atau hampir sama. ${ }^{17}$

Pembaharuan produk pemikiran hukum Islam melalui yurisprudensi dipandang perlu dan baik. Dikatakan demikian karena yuriprudensi disamping menggambarkan keadilan yang tumbuh dan berkembang dalam masyarakat, juga selaras dengan kesadaran hukum masyarakat muslim Indonesia, dengan catatan bahaw hakim Pengadilan Agama yang membuat yurisprudensi itu, selain paham benar tentang hukum Islam, juga memperhatikan dengan sungguh-sungguh nilainilai hukum pada umumnya yang terdapat dalam masyarakat.

Lebih jauh dapat dikatakan bahwa pembaharuan hukum Islam melalui yurisprudensi dianggap sebagai sesuatu yang baik, didasarkan atas beberapa alasan bahwa putusan hakim (yurisprudensi) mempunyai kekuatan mengikat, terutama kalau keputusan itu dikelurakan oleh Pengadilan Tinggi atau Mahkamah Agung. ${ }^{18}$ Di samping itu, yurisprudensi lebih menyentuh masalah-masalah praktis dalam tatanan sosial kemasyarakatan.

\footnotetext{
${ }^{15}$ M. Atho Mudzhar, Fatwa-Fatwa Majelis Ulama, h. 2.

${ }^{16}$ Cik Hasan Bisri, Menggagas Fikih Sosial, h. 130-131.

${ }^{17}$ M. Daud Ali, Hukum Islam dan Peradilan Agama: Kumpulan Tulisan (Jakarta: Rajawali Pers, 1997), h. 358.

${ }^{18}$ M. Daud Ali, Hukum Islam dan Peradilan Agama: Kumpulan Tulisan, h. 360.
} 
Dalam konteks tersebut, yurisprudensi sebagai produk pemikiran hukum Islam dapat dikatakan dinamis karena merupakan respon terhadap perkara-perkara nyata yang dihadapi masyarakat. yurisprudensi memang tidak meliputi semua aspek pemikiran hukum Islam sebagaimana halnya dengan fikih, akan tetapi dari segi kekuatan ia lebih mengikat terutama bagi pihak-pihak yang berperkara.

\section{Perundang-undangan}

Peraturan perundang-undangan sebagai salah satu wujud pemikiran hukum Islam, seperti halnya dengan yurisprudensi atau putusan pengadilan ia bersifat mengikat. Bahkan daya ikatnya lebih luas dalam masyarakat, karena tidak hanya pada pihak-pihak tertentu, akan tetapi juga seluruh masyarakat yang ada di wilayah hukumnya. Unsur-unsur yang terlibat dalam dalam perumusan perundangundangan tidak terbatas pada golongan ulama (fuqaha) saja, akan tetapi juga melibatkan unsur-unsur lain dalam masyarakat seperti cendikiawan, politisi, dan lain-lain. Masa berlakunya suatu UU berlangsung sampai adanya peraturan Perundang-undangan yang baru yang menggantikannya. ${ }^{19}$

Di antara produk pemikiran hukum Islam produk pemikiran hukum Islam yang telah diakomodasi dalam kategori peraturan Perundang-undangan antara lain; UU no 1 tahun 1974 tentang perkawinan, Inpres no 1 tahun 1991 tentang Kompilasi Hukum Islam yang mengatur tentang kewarisan, perkawinan, perwakafan, hibah, shadaqah, wasiat, dan lain-lain. Sebagai produk pemikiran hukum Islam, UU memberikan sanksi terhadap orang melakukan pelanggaran. Sebagaimana produk kolektif, UU memiliki daya ikat yang lebih luas dalam keputusan pengadilan. Dalam hal ini yang terpenting harus dimiliki oleh UU sebagai produk pemikiran hukum Islam adalah kualitas yang tinggi dan dapat mencerminkan realitas hukum yang tumbuh dan berkembang dalam masyarakat.

\section{Pembaharuan Hukum Materil dalam Kompilasi Hukum Islam}

Secara sosiologis, KHI secara nyata menjadi buku hokum, pedoman hokum, kitab hukum, hukum yang mandiri dan ijtihadi' serta ijma' umat Islam Indonesia. Bahkan lebih jauh daripada itu, menurut Cik Hasan Bisri, Kompilasi Hukum Islam merupakan upaya akomodatif dari mazhab-mazhab fikih klasik. Kendatipun demikian, tidak dapat dipungkiri bahwa materi hukum dalam KHI masih didominasi oleh mazhab Syafi' i. ${ }^{20}$ Dikatakan demikian karena 38 kitab mu'tabarah yang dijadikan rujukan dalam penyusunan KHI, pada umumnya ditulis oleh ulama yang bermazhab Syaf'i.

Terkait dengan materi hukum dalam KHI, tampaknya mengikuti bahasa hukum yang berlaku dalam dunia hukum dan peraturan Perundang-undangan. Materi hukum yang tertuang dalam KHI bersifat umum, misalnya dalam kaitannya dengan

\footnotetext{
${ }^{19}$ Atho Mudzhar, Fatwa-Fatwa Majelis Ulama, h. 3.

${ }^{20}$ Cik Hasan Bisri (ed.), KHI dan PA dalam Sistem Hukum nasional (Jakarta: Logos Wacana Ilmu, 1999), h.15.
} 
masalah larangan perkawinan karena sesusuan. Dalam KHI hanya menyebutkan ketentuan umum tentang larangan perkawinan karena pertalian sesusuan (pasal 39 ayat a-d). ${ }^{21}$ Sedangkan dalam fikih, terutama pemikiran para fuqaha mazhab, larangan perkawinan karena sesusuan dijelaskan secara rinci mengenai syarat dan kuantitas penyusuan yang mengakibatkan larangan perkawinan. ${ }^{22}$

Mencermati lebih jauh materi Kompilasi Hukum Islam, tampaknya belum melepaskan diri dari pengaruh mazhab fikih aliran Timur Tengah. Bahkan kuatnya pengaruh fikih Timur Tengah tampak dalam penyusunan KHI dengan melakukan studi banding ke Timur Tengah. ${ }^{23}$ Pengaruh mazhab fikih dalam KHI, dapat dilihat pada materi-materi hukum dalam KHI, antara lain:

1) Saksi pernikahan

Salah satu rukun nikah adalah adanya saksi sesuai dengan hadis yang diriwayatkan oleh Ibnu Abbas bahwa tidak sah suatu perkawinan tanpa wali dan dua orang saksi yang adil. Para ulama mazhab seperti Syafi'I, Maliki, Hambali, dan Hambali sepakat bahwa bukti pernikahan harus ada saksi-saksi laki-laki atau seorang seorang laki-laki dan dua orang perempuan, dan kesaksian wanita saja tidak diterima, serta dipersyaratkan perlunya sifat adil dalam diri saksi. Sementara mazhab Hanafi dan Imamiyah membolehkan saksi perempuan atau gabungan seorang laki-laki dan seorang perempuan, tanpa persyaratan dan sifat adil. ${ }^{24}$ Dalam KHI pasal 24 ayat 1-2 disebutkan tentang kedudukan saksi dan jumlah saksi, yaitu: 1) saksi dalam pernikahan merupakan rukun pelaksanaan nikah, 2) Setiap pernikahan harus disaksikan oleh dua orang saksi. Demikian pula dalam pasal 25 menyebutkan tentang syarat saksi, yaitu: seorang laki-laki muslim, adil, aqil balig, tidak terganggu ingatan dan tidak tuna rungu atau tuli. ${ }^{25}$ Ketentuan ini menganut pendapat mazhab Maliki, Syafi'i, dan Hanabila.

2) Penerima wasiat dari ahli waris.

Dalam KHI pasal 195 (3) disebutkan bahwa wasiat kepada ahli waris berlaku bila disetujui oleh ahli waris lain. Ketentuan ini tampaknya diilhami oleh pendapat jumhur ulama yang mengatakan bahwa ahli waris boleh menerima wasiat apabila disetujui oleh ahli waris lainnya, walaupun terdapatahli waris lain yang tidak setuju.

Kendatipun KHI masih kental dengan pengaruh mazhab fikih aliran Timur Tengah, juga tidak dapat dipungkiri bahwa dalam KHI terdapat materi hukum yang merupakan terobosan baru ulama Indonesia yang merupakan bentuk pembaharuan terhadap hukum Islam. Dan dalam perkembangannya selanjutnya tidak menutup kemungkinan untuk terus melakukan pembaharuan terhadap hukum materil

\footnotetext{
${ }^{21}$ Abdurrahman, Kompilasi Hukum Islam (Jakarta: Akademika Pressindo, 1992), h. 122.

${ }^{22}$ An-Nawawi, Shahih Muslim bi Syarh an-Nawawi, Jilid V (Beirut: Dar al-Fikr, t.th.), h. 30

${ }^{23}$ Ahmad Rofik, Hukum Islam di Indonesia (Jakarta: Rajawali Pers, 1995), h. 35.

${ }^{24}$ Muhammad Jawad al-Mughniyah, Al-Fiqh 'Ala Mazahib al-Khamsah, diterjemahkan oleh Alif Muhammad dengan judul Fikih Lima Mazhab, Juz II; Jakarta: Basrie Pers, 1994), h. 26.

${ }^{25}$ Abdurrahman, Kompilasi Hukum Islam di Indonesia, h. 119.
} 
Peradilan Agama tersebut.

Pembaharuan terhadap Kompilasi Hukum Islam tersebut tertuang dalam konsideran Instruksi Presiden yang menyatakan bahwa KHI tersebut terbuka untuk dikembangkan, sesuai dengan perkembangan zaman dan pemenuhan kebutuhan hukum ummat Islam Indonesia. ${ }^{26}$

Adapun isi KHI yang merupakan bentuk pembaharuan atas hukum Islam yang ada dalam fikih-fikih klasik antara lain: harta bersama dalam perkawinan, pencatatan nikah, ta'lik talak, wasiat wajibah, sertifikasi wakaf, dan lain-lain.

Agar mendapatkan gambaran mengenai pembaharuan hukum tersebut, pada makalah ini penulis mencoba memaparkan tiga dari beberapa hal yang telah mengalami pembaharuan hukum dalam KHI, yaitu: ta'lik talak, harta bersama dalam perkawinan, dan wasiat wajibah.

\section{Ta'lik Talak}

KHI membenarkan cara lain bagi seorang istri untuk dapat bercerai dari suaminya, yaitu melalui institusi ta'lik talak. Meskipun cara perceraian yang paling umum dilakukan dalam ikatan perkawinan orang-orang Islam Indonesia adalah melalui institusi talak.

Dalam KHI pasal 45 disebutkan bahwa kedua calon mempelai dapat mengadakan perjanjian perkawinan dalam bentuk: ${ }^{27}$

- Ta'lik talak

- Perjanjian lain yang tidak bertentangan dengan hukum Islam

Pembaharuan terhadap hukum Islam tersebut dilakukan mengingat, di Indonesia, merupakan hal yang biasa bagi suami muslim untuk mengucapkan ta'lik talak pada saat memulai suatu perkawinan, dimana ia mengajukan syarat bahwa, jika ia menyakiti istrinya atau tidak menghiraukannya selama jangka waktu tertentu, maka pengaduan istri terhadap Pengadilan Agama akan menyebabkan si istri tersebut terceraikan. ${ }^{28}$

Penelitian terhadap institusi ta'lik talak ini membuktikan adanya integrasi antara elemen-elemen yang berasal dari hukum adat dan hukum Islam. Walaupun pengaruh hukum Islam dalam hal ini lebih dominan, namun peran hukum adat dalam rangka menjadikan ta'lik talak sebagai alat yang efektif bagi istri untuk mengakhiri perkawinannya tampak sangat jelas. Elemen yang diambil dari hukum adat yang secara jelas berperan di sini adalah pengakuan atas hak istri untuk mengajukan perceraian, suatu bentuk yang sudah lama ada dalam hukum perkawinan Islam di Indonesia.

2. Harta Bersama dalam Perkawinan

Adapun dalam KHI diatur dalam bab XIII pasal (85-97). Dalam bab tersebut

\footnotetext{
${ }^{26}$ Mohammad Daud Ali, Hukum Islam dan Peradilan Agama: Kumpulan Tulisan, h.376.

${ }^{27}$ H. Abdurrahman, Kompilasi Hukum Islam di Indonesia (Jakarta: Akademika Pressindo, 1992), h. 72.

${ }^{28}$ Ratno Lukito, Pergumulan Antara Hukum Islam Dan Adat Di Indonesia (Jakarta: INIS, 1998), h. 78.
} 
tidak ada disebut mengenai terjadinya harta bersama, sebagaimana diatur dalam pasal 35 Undang-Undang No.1 Tahun 1974. ${ }^{29}$ Akan tetapi, dalam pasal 1 huruf $\mathrm{f}$ disebutkan harta kekayaan dalam perkawinan atau syirkah adalah harta yang diperoleh baik sendiri-sendiri atau bersama suami istri selama dalam ikatan perkawinan berlangsung dan selanjutnya disebut harta bersama, tanpa mempersoalkan terdaftar atas nama siapapun. ${ }^{30}$ Pasal-pasal selanjutnya dari kompilasi memberikan pengaturan cukup rinci mengenai masalah harta bersama ini.

Dalam hukum Islam, harta bersama suami istri pada dasarnya tidak dikenal, karena hal ini tidak dibicarakan secara khusus dalam kitab fikih. Namun konsep harta bersama dalam perkawinan ini meruakan produk hukum adat yang tereduksi dari nilai-nilai lokal sebagai bentuk keseimbangan hak antara suami istri dalam kehidupan perkawinan. Mengenai klaim terhadap harta benda tersebut, maka kedua partner dalam ikatan perkawinan tersebut dipandang sebagai dua pihak yang mempunyai hak-hak yang sama di bawah hukum, karena "memelihara rumah tangga sejak dahulu dipandang sebagai tugas yang harus dipikul bersama secara seimbang oleh kedua belah pihak". ${ }^{31}$ Hingga kemudian, harta bersama yang diperoleh selama perkawinan, oleh karenanya, dimiliki secara bersama oleh keduanya.

\section{Wasiat Wajibah}

Persoalan wasiat wajibah dalam KHI dapat ditemukan dalam bab V pasal 194209. ${ }^{32}$ Aturan mengenai wasiyat wajibah yang ada dalam KHI merupakan reformasi hukum, pemberian bagian harta warisan sebanya 1/3 bagi anak angkat dan orang tua angkat sebagai bentuk penyesuaian ketetapan hukum berdasar atas kebiasaan masyarakat di Indoneisa.

Dalam fikih klasik tidak ditemukan adanya bagian untuk anak angkat dan orang tua angkat, tapi yang ada hanyalah ketentuan untuk memberikan kepada keluarga dekat. Namun kemudian masalah muncul untuk menentukan kerabat dekat yang mana yang akan menerima wasiat tersebut. Untuk menjawab hal ini, maka interpretasi (ijtihad) sangat diperlukan.

Sesuai dengan hukum adat, umum terjadi dalam keluarga Indonesia untuk mengadopsi seorang anak laki-laki atau perempuan, untuk kemudian dimasukkan dalam lingkungan keluarga mereka. Sehingga, oleh para ahli hukum Islam Indonesia merasa berkewajiban untuk menjembatani kesenjangan lembaga adopsi ini, maka para ahli hukum Islam Indonesia beusaha untuk mengakomodasi sistem nilai yang ada dalam kedua hukum dengan jalan mengambil dari institusi wasiat wajibah yang berasal dari hukum Islam sebagai sarana untuk fasilitas nilai moral yang ada dibalik

${ }^{29}$ H.M.A. Tihami dan Sohari Sahrani, Fikih Munakahat: Kajian Fikih Nikah Lengkap (Jakarta: Rajawali Pers, 2009), h. 180.

${ }^{30}$ H. Abdurrahman, Kompilasi Hukum Islam di Indonesia, h. 74.

${ }^{31}$ Ratno Lukito, Pergumulan Antara Hukum Islam Dan Adat Di Indonesia, h. 82.

${ }^{32}$ H. Abdurrahman, Kompilasi Hukum Islam di Indonesia, h. 81. 
paktek adopsi dalam hukum adat.

Atas penjelasan ketiga bentuk pembaharuan hukum tersebut di atas, menggambarkan bahwa antara adat kebiasaan yang terjadi di masyarakat dan hukum Islam dapat selalu terjadi kesesuaian antara keduanya. Hal tersebut merupaan sebuah keniscayaan dalam perkembangan hukum di Indonesia untuk tetap melakukan pembaharuan terhadap hukum yang berlaku di masyarakat terlebih lagi terhadap hukum keluarga, Kompilasi Hukum Islam, yang dijadikan sebagai pedoman dalam kehidupan keluarga muslim di Indonesia.

\section{PENUTUP}

Mengacu dari uraian yang telah dikemukakan di atas, ditarik kesimpulan sebagai berikut:

1. Pembaharuan hukum Islam dalam konteks Kompilasi Hukum Islam dipandang sebagai amanah konstitusi Negara untuk menggantikan produk-produk hukum kolonial Belanda yang masih berlaku dan untuk menggantikan beberaa produk hukum yang dipandang tidak sesuai dengan tuntutan zaman.

2. Pembaharuan hukum Islam dalam konteks hukum keluarga Indonesia meliputi empat kategori, yaitu: fikih, fatwa, yurisprudensi, dan Undang-Undang.

3. Kompilasi Hukum Islam merupakan rumusan fikih ala Indonesia yng dijadikan sebagai pedoman dan rujukan umat Islam Indonesia. KHI sebagai rumusan fikih, meniscayakan untuk ditafsir sesuai dengan konteksnya. Hal tersebut dapat dilihat dalam beberapa ketentuan hukum yang ada dalam KHI.

\section{Daftar Pustaka}

Abdurrahman, Kompilasi Hukum Islam di Indonesia, Jakarta: Akademika Pressindo, 1992.

Anderson, J.N.D., Islamic law in Moderen World, alih bahasa oleh Machnun Husain, dengan judul: Hukum Islam di Dunia Moderen, Cet.I; Surabaya: Amar Press, 1991.

Al-Jauziyyah, Ibnu Qayyim, al-Jauziyyah, I'lam al-Muwaqqi'in 'an Rab al-'Alamin, Juz III, Beirut: Dar al-Fikr, t.th.

Al-Mughniyah, Muhammad Jawad, Al-Figh 'Ala Mazahib al-Khamsah, diterjemahkan oleh Alif Muhammad dengan judul Fikih Lima Mazhab, Juz II; Jakarta: Basrie Pers, 1994

Ali, M. Daud, Hukum Islam dan Peradilan Agama: Kumpulan Tulisan, Jakarta: Rajawali Pers, 1997.

An-Nawawi, Shahih Muslim bi Syarh an-Nawawi, Jilid V, Beirut: Dar al-Fikr, t.th.

Ash-Shiddiqy, Hasbi, Syari'at Islam Menjawab Tantangan Zaman, Jakarta: Bulan Bintang, 1966. 
Bisri, Cik Hasan, Menggagas Fikih Sosial, Cet. I; Mizan: 1995.

-, (ed.), KHI dan PA dalam Sistem Hukum nasional, Jakarta: Logos Wacana Ilmu, 1999.

Jatnika, Rahmat, Jalan Mencari Hukum Islam Upaya ke Arah Pemahaman metodologi Ijtihad, dalam Amrullah Ahmad SF., Dimensi Hukum Islam dalam Sistem hukum Nasional, Cet. I, Jakarta: Gema Insani Press, 1996.

Jazuli A., Ilmu Fikih: Sebuah Penganta`r, Cet.I; Bandung: Orba Shakti, 1991.

Lukito, Ratno, Pergumulan Antara Hukum Islam Dan Adat Di Indonesia, Jakarta: INIS, 1998.

Mudzhar, M. Atho, Fatwa-Fatwa Majelis Ulama, Cet. I; Jakarta: INIS, 1993.

Rofik, Ahmad, Hukum Islam di Indonesia, Jakarta: Rajawali Pers, 1995.

Tihami, H.M.A. dan Sohari Sahrani, Fikih Munakahat: Kajian Fikih Nikah Lengkap, Jakarta: Rajawali Pers, 2009.

Wahid, Marzuki dan Rumadi, Fikih Mazhab Negara, Cet. I; Yogyakarta: LkiS, 2001.

Yafi, Ali, Menggagas Fikih Sosial, Cet. I; Bandung: Mizan, 1995.

---------, Fikih Sosial, Cet. I; Jakarta: Wacana Ilmu, 1994. 